\title{
A Research for Determining Psychosocial Risk Factors among Health Employees
}

\author{
Harun Kirilmaz ${ }^{1}$, Gulcan Santas ${ }^{2}$ \\ ${ }^{1}$ Department of Health Management, Sakarya University, Sakarya, Turkey \\ ${ }^{2}$ Department of Health Management, Hacettepe University, Ankara, Turkey \\ Email: hkirilmaz@sakarya.edu.tr
}

How to cite this paper: Kirilmaz, H. and Santas, G. (2016) A Research for Determining Psychosocial Risk Factors among Health Employees. Open Access Library Journal, 3: e3149.

http://dx.doi.org/10.4236/oalib.1103149

Received: November 9, 2016

Accepted: December 3, 2016

Published: December 6, 2016

Copyright $\odot 2016$ by authors and Open Access Library Inc.

This work is licensed under the Creative Commons Attribution International

License (CC BY 4.0).

http://creativecommons.org/licenses/by/4.0/

\begin{abstract}
This descriptive study aims to determine the psychosocial risk factors among health employees. The research was conducted in a public hospital in Turkey between August 2015 and September 2015. Checklists were taken from "Occupational Health and Safety Risks in the Healthcare Sector", published under European Community Programme for Employment and Social Solidarity. Cronbach's alpha value was found as 0.71 for checklist with 90 items. All analyses were performed with version 18 of Statistical Package for Social Sciences (SPSS). The data were expressed as percent, \pm standard deviation and mean. Participants were mostly nurses $(85.2 \%), 59.1 \%$ was graduate degree, and $43.5 \%$ was working for less than 5 years. The study demonstrates that risk factors associated with burnout are at "high level" among $66.1 \%$ of health employees and risk factors related to mobbing are at "high level" among $42.6 \%$ of health employees who work in hospital. Health employees have increased levels of risk in stress and violence (76.5\%). In addition, the study shows that risk factors related to burnout are at "high level" among $75 \%$ of physician and risk factors about stress are at "high level" among 25\% of them, and $83.3 \%$ of physicians have "increased risk" about mobbing and violence.
\end{abstract}

\section{Subject Areas}

Health Policy

\section{Keywords}

Health Employees, Risk, Psychosocial Factors, Burnout, Mobbing, Stress, Violence

\section{Introduction}

Work-related stress and tension occurs because of work overload, serving to patients 
with serious and terminally ill, necessity of emotional support for patients and their relatives in health sector. In addition, deficiencies in health care and imbalances in service and staffing lead to the loss of motivation and tension among health employees. Work-related stress and burnout produce mental effects such as depression, anxiety, feelings of helplessness, physiological influences, headache, muscle tension, insomnia. There are also many negative organizational results of work-related stress, such as reduction in work efficiency, work delay, absenteeism with apology, leave the job completely, retention risk of experienced employees. Conducting necessary implementation and regulations is important for realizing and eliminating the burnout experienced by employees. Implementation and regulations depend on the managers' knowledge level associated with the issue and the importance of issue.

Burnout is a common problem especially in the service sector. Health employees are known as one of the risk groups for burnout [1]. Burnout is defined as the physical and emotional collapse arising from working conditions. Although burnout is seen in many areas today, it is observed especially among physicians, nurses and physiotherapy in which the profession requires intense and persistent human relationship.

Hospitals are one of the areas requiring intense human relationships. Communication with patients, their relatives and within health employees is extremely important. Peacefully working employees increase the productivity in the workplace. Increasing industrial accidents, rising permits and absenteeism are perceived as negative by employees and organization. Recent researches show that there are many discussions on the phenomenon of mobbing in workplace [2].

Emotional lynch, psychological terror, trauma, bullying, emotional assault, intimidation and emotional abuse are among the words, which are used instead of mobbing. The attacker, abusive, emotional attacker and mobbing attacker are preferred to explain the person applying the mobbing. Mobbing victim is used for the person suffering from emotional attack [3].

This study discusses the psychosocial risk factors among health employees. The conceptual framework of the study focuses on mobbing, drug use, drug addiction and stress in health sector. The scale was developed by the help of a publication called "Occupational Health and Safety Risks in the Healthcare Sector" [4]. The scale was adapted to Turkish and implemented among health employees in a public hospital. Lastly, the study aims to reveal the psychosocial risk factors in terms of title, education level, gender, length of service and units of health employees.

\section{Conceptual Framework}

\subsection{Mobbing in Health Sector}

Considering working conditions and work environment in the health sector, employees may be exposed to mobbing more than other sectors, due to the intensity of female employees, long working hours, excessive work stress, the profile of people being served (consisting of patients and their relatives), etc. Mobbing among nurses has been studied in many researches, and these studies are mostly associated with exposure to mobbing 
and the possibility of reflection to work life [5].

Because of many negative factors caused by the work environment, health care is regarded as a stressful service with its work overload. Problems in the environment affect health employees physically, psychologically and socially. If the business environment oblige health employees to leave the organization, productivity may decrease by affecting the service quality [6] [7]. Nurses are firstly referenced health personnel within medical team by patients and their families for 24 hours. They play a key role by providing communication within the health team. With the effect of many negative factors resulting from work environment, nursing is qualified as a stressful profession with work overload. The main stressors of nurses were described as conflicts with managers, role conflict and ambiguity, work overload, emotional stress experienced due to patients, working with patients who need intensive care and dying, conflicts with patients and work with shift [8].

The probability of occupational risks in health employees varies according to profession, work done and units. Considering the spending more time with patients and directly serving health care to patients, nurses' health risks are higher than other health professionals [9] [10] [11].

Health employees have stress-related risk factors such as long-term work, excessive workloads, time pressures, difficult or complex tasks, insufficient rest periods, uniformity and physically poor working conditions. In addition, they are faced with standing for long periods, insomnia due to shifts and eating disorders depending on the density of services during treatment [10] [12]. Therefore, the evaluation of work environment and working conditions is important for health employees [7].

Nursing includes sacrifice, resistance and physical strength, hence it requires to be healthy physically and mentally in order to be more beneficial for patients. Nurses work by standing for long time and have dense and irregular sleeping hours. It is a profession that requires patience, dedication and physical strength. They should pay attention to their health to be beneficial for patients. They have inadequate recreational facilities and excessive workload [12] [13].

Studies indicate that nurses are at greater risk than other health professionals [13] [14]. There are environmental and organizational factors affecting nurses' job satisfaction. Environmental and organizational factors can be listed as job security, development and promotion opportunities, work environment and conditions, management style, relationship between manager and colleagues. Expected working conditions of nurses lead to liking the profession, an increase in work efficiency and high success in service. Given the difficulties of nurses in failure in equipment, lack of personnel, irregular working hours, lack of cooperation and lack of social amenities, service quality and job satisfaction decrease and this situation is concluded with leaving from job [13].

\subsection{Drug Use and Addiction among Health Employees}

Drug addiction is a serious disease which disrupts the individual's physical and mental health, and damages to the harmony between family, society and work. It has genetic 
and neurobiological basis [15]. All over the world, intensive researches are conducted for determining the frequency of drug use and developing new ways of psychosocial and pharmacological treatment. In recent years, researches have been conducted to determine the frequency of drug use in Turkey. The studies reveal the frequency of drug use among students, health employees and workers. They report that the risk of drug use from up to $5 \%$ and the risk of alcohol and drug use between $10 \%$ to $30 \%$ [16] [17].

Drug use is important among health employees both for their health and patients' health in terms of public health. The presence of drugs and easily access to them cause addiction among health employees. Although the findings are insufficient on drug use among health professionals, researches show that drug use are similar among health employees with overall community [18]-[23].

Professional difficulties, erosion of the taboo against the use of injection and especially easy access to drugs may direct health employees to drug use and addiction. Risk factors for addiction among health care employees are similar to the general population: Chaotic childhood, narcissistic personality traits, using more than one pack of cigarettes per day, a family history of alcoholism, regular alcohol use, the presence of other psychiatric disorders, experiencing of emotional problems, stress at home or work, seeking adventure, attempting to treat yourself, chronic fatigue, easy access to drugs, denial and permissive environment.

The American Nurses Association predicts the rate of drug use among nurses as $10 \%$ to $20 \%$ [19]. A research from Denizli was found the rate of drug use among nurses as $2.8 \%$ [24]. In this study, it was found that nurses used most commonly sedatives and sleeping pills. The study revealed that the most commonly used drugs were meperidine hydrochloride, amphetamines, alcohol and benzodiazepines among health employees. In addition, the use of pethidine is remarkable among health employees for Turkey [21].

\subsection{Stress in Health Sector}

Stress is commonly faced among health employees during service delivery. The concept, firstly suggested in the 1930s by Hans Selye, is defined as individuals' acting and reacting against any physical or psychological stimulus to ensure mental and physical harmony [25] [26] [27] [28] [29].

Stress is a two-way case [30]. Despite the negative dimension, it has also a positive value. As stress reduces performance, it may increase as well. There are many causes and consequences of psychological and physiological situation in organism. Therefore, it is necessary to understand by reviewing the basic structure of stress (requests, responses and results).

Job stress poses a significant problem for people in the organization. It is an undesirable concept that results in mental and physical illness, leading to insufficient struggle with sources of physical stress cooperating with work itself [31] [32] [33] [34] [35]. The sources of stress in the organization can be divided into four groups: organizational policies, structural characteristics of organization, physical conditions and organiza- 
tional processes. As long as organizations grow and become complex structure, the sources of stress affecting individuals increases and rises to a level more difficult to control the organization [36].

Job satisfaction is one of the most trend topics in the field of management since the 1940s. It is an emotional response resulting from interaction of values against employees' own business and earnings from job [37] [38] [39] [40]. Employees, having positive attitudes towards the job, experience happiness as a priority. Sufficient level of job satisfaction will allow the realization of positive results such as job loyalty, efficient operation, reduced wastage, etc. Dissatisfaction from job is painful and can lead to negative emotions for employees. Causing anxiety mentally and dissatisfaction from job and continuity of this anxiety can affect mental health in a negative way. Additionally, undesirable behaviors can occur such as employee frustration, leaving from job, absenteeism, belligerence, etc. Job dissatisfaction can cause psychosomatic origin diseases (ulcer, heart disease) by affecting the physical health of employees [41].

\section{Method}

This research is a descriptive study in order to identify psychosocial risk factors among health employees. The research was conducted in a public hospital in Turkey between August 2015 and September 2015. After receiving the permission from hospital management, health employees who wished to participate, agreed to answer the questionnaire and gave verbal consent was included in the study.

\section{Data Collecting Tools}

Data collection tool is composed of seven parts. First part includes 7 questions about demographic characteristics (title, age, gender, education level, the time worked in the hospital, work experience in the civil service). Stress in the second part, burnout in the third part and violence in the fourth part are discussed. There are fifteen-item checklist including working hours in the sixth part and the risk factors associated with drug addiction in the seventh part.

Checklists were obtained from the publication called "Occupational health and safety risks in the healthcare sector", published under the European Community Programme for Employment and Social Solidarity [4]. The items in checklist were examined in terms of reliability. As a result, Cronbach's alpha value was 0.71 in checklist with 90item.

The study was applied to health employees who wanted to participate in the research, agreed to answer the questionnaire and gave verbal consent. In order to not make employee to feel under pressure and answer the questions with freewill, the questionnaire was given to them and collected after a while. Thus, it was ensured to be granted the objective answers to questions.

The items in checklists were evaluated by the answer "Yes" or "No". The answers, demonstrated that there was a risk, were given "1" point and others were given "0" point. The evaluation of the data was done by SPSS 18 software. For the evaluation of 
each part, number, percentage and standard deviation values of items were calculated with descriptive statistical methods. So the data were expressed with mean and \pm standard deviation. The total risk scores were evaluated by "no risk" between 1 - 5 points; "increased risk" between 6 - 10 points and "high risk" between 11 - 15 points.

\section{Findings}

\subsection{Socio-Demographic Results}

As shown in Table 1, the participants of the study included mostly nurses (85.2\%). Health employees in the study were mostly undergraduate (59.1\%), $87 \%$ were women, and $43.5 \%$ were less than 5 years as work experience.

\subsection{General Psychosocial Risk Factors}

As shown in Table 2, 66.1\% of the health employees had burnout at "high risk", $42.6 \%$ had mobbing at "high risk" and $76.5 \%$ were at "increased risk" level of stress and violence.

Table 1. Demographic characteristics of participants $(n=115)$.

\begin{tabular}{cccccc}
\hline Title & $\mathbf{n}$ & $\%$ & Work Experience & $\mathbf{n}$ & $\%$ \\
\hline Physician & 12 & 10.4 & $0-5$ Year & 50 & 43.5 \\
Nurse & 98 & 85.2 & $6-10$ Year & 39 & 33.9 \\
Medical officers & 5 & 4.3 & $11-15$ Year & 16 & 13.9 \\
Education & $\mathbf{n}$ & $\%$ & $16-20$ Year & 10 & 8.7 \\
High School & 16 & 13.9 & Working Unit & $\mathbf{n}$ & $\%$ \\
Associate degree & 10 & 8.7 & Internal Clinics & 40 & 34.8 \\
Undergraduate & 68 & 59.1 & Surgical Clinics & 42 & 36.5 \\
Post Graduate & 21 & 18.3 & Outpatient Clinics & 2 & 1.7 \\
Gender & $\mathbf{n}$ & $\%$ & Emergency Service & 6 & 5.2 \\
Male & 15 & 13.0 & Laboratory & 2 & 1.7 \\
Female & 100 & 87.0 & Intensive Care Unit & 23 & 20.0 \\
\hline
\end{tabular}

Table 2. General psychosocial risk factors.

\begin{tabular}{ccccccc}
\hline & \multicolumn{2}{c}{ No Risk } & \multicolumn{2}{c}{ Increased Risk } & \multicolumn{2}{c}{ High Risk } \\
\cline { 2 - 7 } & $\mathbf{n}$ & $\%$ & $\mathbf{n}$ & $\%$ & $\mathbf{n}$ & $\%$ \\
\hline Stress & 7 & 6.1 & 88 & 76.5 & 20 & 17.4 \\
Burnout & 0 & 0 & 39 & 33.9 & 76 & 66.1 \\
Violence & 6 & 5.2 & 88 & 76.5 & 21 & 18.3 \\
Mobbing & 1 & 0.9 & 65 & 56.5 & 49 & 42.6 \\
Working Time & 5 & 4.3 & 87 & 75.7 & 23 & 20.0 \\
Drug Addiction & 63 & 54.3 & 48 & 41.7 & 4 & 3.5 \\
\hline
\end{tabular}




\subsection{Psychosocial Risk Factors by Titles}

When examined psychosocial risk factors of health employees by title, education level, gender, work experience and unit, which were taken as independent variables, there was no significant statistical relationship between education, gender, work experience, units and psychosocial risk factors.

Table 3 shows the situation of the physicians who were exposed to psychosocial risk. According to the findings, 75\% of physicians had burnout at "high risk", 25\% of those had stress at "high risk" and $83.3 \%$ of those had "increased risk" of mobbing and violence in the study.

Table 4 shows the exposure of health nurses to psychosocial risk factors. According to the table, $63.3 \%$ of nurses had burnout at "high risk", $46.9 \%$ had mobbing at "high risk", $77.6 \%$ had "increased risk" of stress and $76.5 \%$ had "increased risk" of violence.

When examined the exposure of medical officers to psychosocial risk factors, $100 \%$ of medical officers had burnout at "high risk", $40 \%$ of those had violence at "high risk" and $80 \%$ of those had "increased risk" of mobbing (Table 5).

\section{Discussion}

Health employees are exposed to stress, burnout, violence and mobbing. These factors are among the serious occupational health and safety risks. This study aims to identify psychosocial risk factors among health employees.

Table 3. Psychosocial risk factors in physicians.

\begin{tabular}{ccccccc}
\hline & \multicolumn{2}{c}{ No Risk } & \multicolumn{2}{c}{ Increased Risk } & \multicolumn{2}{c}{ High Risk } \\
\cline { 2 - 6 } & $\mathbf{n}$ & $\%$ & $\mathbf{n}$ & $\%$ & $\mathbf{n}$ & $\%$ \\
\hline Stress & 0 & 0 & 9 & 75.0 & 3 & 25.0 \\
Burnout & 0 & 0 & 3 & 25.0 & 9 & 75.0 \\
Violence & 1 & 8.3 & 10 & 83.3 & 1 & 8.3 \\
Mobbing & 0 & 0 & 10 & 83.3 & 2 & 16.7 \\
Working Time & 0 & 0 & 12 & 100.0 & 0 & 0 \\
Drug Addiction & 10 & 83.3 & 2 & 16.7 & 0 & 0 \\
\hline
\end{tabular}

Table 4. Psychosocial risk factors in nurses.

\begin{tabular}{ccccccc}
\hline & \multicolumn{2}{c}{ No Risk } & \multicolumn{2}{c}{ Increased Risk } & \multicolumn{2}{c}{ High Risk } \\
\cline { 2 - 7 } & $\mathbf{n}$ & $\%$ & $\mathbf{n}$ & $\%$ & $\mathbf{n}$ & $\%$ \\
\hline Stress & 7 & 7.1 & 76 & 77.6 & 15 & 15.3 \\
Burnout & 0 & 0 & 36 & 36.7 & 62 & 63.3 \\
Violence & 5 & 5.1 & 75 & 76.5 & 18 & 18.4 \\
Mobbing & 1 & 1.0 & 51 & 52.0 & 46 & 46.9 \\
Working Time & 4 & 4.1 & 73 & 74.5 & 21 & 21.4 \\
Drug Addiction & 51 & 52.0 & 43 & 43.9 & 4 & 4.1 \\
\hline
\end{tabular}


Table 5. Psychosocial risk factors in medical officers.

\begin{tabular}{ccccccc}
\hline & \multicolumn{2}{c}{ No Risk } & \multicolumn{2}{c}{ Increased Risk } & \multicolumn{2}{c}{ High Risk } \\
\cline { 2 - 6 } & $\mathrm{n}$ & $\%$ & $\mathrm{n}$ & $\%$ & $\mathrm{n}$ & $\%$ \\
\hline Stress & 0 & 0 & 3 & 60.0 & 2 & 40.0 \\
Burnout & 0 & 0 & 0 & 0 & 5 & 100.0 \\
Violence & 0 & 0 & 3 & 60.0 & 2 & 40.0 \\
Mobbing & 0 & 0 & 4 & 80.0 & 1 & 20.0 \\
Working Time & 1 & 20.0 & 2 & 40.0 & 2 & 40.0 \\
Drug Addiction & 2 & 40.0 & 3 & 60.0 & 0 & 0 \\
\hline
\end{tabular}

According to the findings, risk factors related to burnout were at "high risk" levels among $66.1 \%$ of health employees. Choosing profession willingly or dissatisfaction from profession are variables that affect burnout. Those who did not choose profession willingly or not satisfied with the profession are more likely to experience burnout [42]-[48]. Studies indicate that the highest risk group is nurses and then general practitioners in terms of burnout among health employees [43] [44] [45] [49] [50] [51] [52]. The excessive number of patients can cause burnout [52]. Studies state that employees working in intensive care units, burn centers, internal departments and emergency units have high levels of burnout [53] [54] [55] [56].

In the light of the study findings, $42.6 \%$ of health employees had mobbing at "high risk", $56.5 \%$ of those have mobbing at "increased risk" level. In the mutual report of The World Health Organization, International Labor Organization and International Council of Nurses, it is examined violence toward health employees in different countries. The report emphasizes that $17 \%$ of employees are exposed to physical violence, $67 \%$ are exposed to verbal violence, $23 \%$ experience psychological violence, $8 \%$ experience sexual violence and $2.7 \%$ are suffered from ethnic violence. It is possible to say that women experience violent behaviors more than men [57]. Additionally, it is stated that men mostly experience physical violence and women are frequently exposure to psychological violence in the workplace. Women exhibits passive-aggressive behavior especially against their own fellow [58]. Similarly, studies demonstrate that nurses have greater risk of experiencing the violence compared to other health care providers [59] [60]. Studies have some differences in percentages. In a study, $97 \%$ of nurses are subjected to verbal violence [61]. Another study reveals that $70 \%$ of nurses experience mobbing [62]. Others found that $21.9 \%$ of nurses suffer from mobbing [63], $86 \%$ of them experience mobbing [64] and $17.4 \%$ of nurses are subjected to mobbing [65].

The findings showed that risk factors associated with stress were found at "increased risk" level. Unsuitable work environment, unsuitable working hours, the great number of patients per nurse, not choosing the profession willingly, working unwillingly and length of average weekly working hours are the main factors that increase job stress among nurses. In addition, not participating in decision process and perception of nurses about job not to contribute to the personal development can trigger job stress 
[66]. In a study, it was found that authorizing by managers and social support are two most important factors in order to determine the factors that affect job stress and job satisfaction among nurses [67]. Another study found a negative correlation between job satisfaction and job stress [68]. In another research, it was stated that there was an uncertainty how much job stress and job stress determinants of nurses in lower-level management affect the performance of employees [69]. One of the studies found that marital status, age, injustice in promotion, imbalance between tasks, conflict with colleagues, no appreciation, long and exhausting working hours and lack of staff cause job stress [70].

To the best of its knowledge, risk factors associated with violence were found at "increased risk" level among $76.5 \%$ of health employees. In a study, it was found that that the rate of exposure to verbal or physical violence by the relatives of patients is $32.1 \%$ and rate of exposure to verbal or physical violence by patients is $30.8 \%$ [71]. A singlecentered study conducted in Turkey was applied to employees in a public hospital and a university hospital in the city center. The study shows that $87.1 \%$ of the group, consisting of specialists, nurses and other employees, are exposed to violent behaviors; $46.9 \%$ of those are suffered from verbal violence, $33.5 \%$ experience the aggressive behaviors and $19.4 \%$ experience physical assaults [72]. One of the studies suggests that the rate of exposure of participants to violence at least once is $49.5 \%$ within last one year [73]. The study demonstrates that $48.3 \%$ of patients are exposed to violence between 1 - 5 times. In this study, the percentage of verbal violence is found as $72.4 \%$, the frequency of physical violence is found as $11.7 \%$ and the rate of sexual violence rate is very low $(0.025 \%)$. The study also refers that employees cannot generally get help during exposure to violence. Most of employees exposed to violence show the feeling of anxiety and uneasiness at high rates after the event. The most important way to reduce the risk of violence is to take sufficient safety measures in the workplace. Even though studies are largely conducted in emergency services, they are also adaptable to other units. Other large-scale measures can be appropriate reporting systems, effective safety training, and ensuring safety area within 24 hours with person in charge, security gates, security cameras, metal detectors and checkpoints, protective acrylic window, and panic alarms [74].

In this study, there was found "increased risk" associated with working time among $75.7 \%$ of health employees. In a study obtained from 320 nurses, $26 \%$ of nurses complain about staff shortages, $18 \%$ of nurses complain about length of working hours and $23 \%$ also complain about excess of night duty [75]. Studies also state that night duties affect health of nurses [76]. Fatigue is placed on the top with $91.2 \%$. Then, nervousness, agitation and insomnia follow with $78 \%$. That study shows that the majority of nurses find their sleep duration insufficient.

\section{Conclusions}

As a result, considering the structure of health sector and the characteristics of health services, it is obvious that health employees face with many psychosocial risk factors, 
particularly burnout, stress, workload, violence and mobbing. Psychosocial risk factors, arising with both systemic, managerial and individual reasons, have negative impacts on health care delivery. They lead to some unexpected and undesirable effects in terms of both patients and their relatives and health employees. It is believed that elimination or reduction of psychosocial risk factors contribute to the delivery of health services which is effective, efficient, quality and keeping patient safety at the forefront. It has also positive effects on the motivation of health employees, job satisfaction, employee satisfaction and safety.

In this context, the determination of psychosocial risk factors gains favor in working conditions, human resource planning, career, and arrangements to be made in the field of occupational health and safety issues. Moreover, it can be beneficial for the implementation of legal and organizational measures, ensuring effective communication with patients and their relatives, informing and training with various tools such as health literacy. Thus, physical and psychological violence may be reduced among health employees.

\section{References}

[1] Gunusen, N.P. and Ustun, B. (2010) A RCT of Coping and Support Groups to Reduce Burnout among Nurses. International Nursing Review, 57, 485-492. https://doi.org/10.1111/j.1466-7657.2010.00808.x

[2] Tinaz, P. (2011) Mobbing in the Workplace. Beta Publications, Istanbul.

[3] Cobanoglu, S. (2005) Mobbing: Emotional Attack and Control Methods in the Workplace. Timas Publications, Istanbul.

[4] European Community Programme for Employment and Social Solidarity (2011) Occupational Health and Safety Risks in the Healthcare Sector.

http://www.eurogip.fr/en/projects/eu-official-documents-eurogip/3499-occupational-healt h-and-safety-risks-in-the-healthcare-sector

[5] Turac, I.S. and Sahin, B. (2014) Determining the State of Being Subject to Mobbing: A Study on Nurses. Eskisehir Osmangazi University Journal of Social Sciences, 15, 87-112.

[6] Kebapci, A. and Akyolcu, N. (2011) The Effects of the Work Environment on Nurse Burnout in Emergency Department. Turkish Journal of Emergency Medicine, 11, 59-67. https://doi.org/10.5505/1304.7361.2011.43827

[7] Tan, M., Polat, H. and Akgün Sahin, Z. (2012) Assessing Perception of Nurses Regarding Work Environments. Journal of Performance and Quality in Health, 4, 67-78.

[8] ILO (2009) ILO Standards on Occupational Safety and Health: Promoting a Safe and Healthy Working Environment. International Labor Office, Geneva.

[9] Karwowski, W., Jang, R.L., Rodrick, D., Quesada, P.M. and Cronin, S.H. (2005) Self-Evaluation of Biomechanical Task Dementia, Work Environment and Perceived Risk of Injury by Nurses: A Field Study. Occupational Ergonomics, 5, 13-27.

[10] Parlar, S. (2008) A Problem That Is Not Considering in Health Workers: Healthy Work Environment. TAF Preventive Medicine Bulletin, 7, 547-554.

[11] Mollaoglu, M., Kars Fertelli, T. and Ozkan Tuncay, F. (2010) Assessment of Perception Relating Work Environment of Nurses Working in Hospital. Firat University Journal of Health Care Services, 15, 17-30. 
[12] Alcelik, A., Deniz, F., Yesildal, N., Mayda, A.S. and Ayakta Serifi, B. (2005) Health Survey and Life Habits of Nurses Who Work at the Medical Faculty Hospital at AIBU. TAF Preventive Medicine Bulletin, 4, 55-65.

[13] Uye, C. (2009) Defining the Situation of Mobbing Experience among the Nurses by Their Managers. Master's Thesis, Halic University, Institute of Medical Sciences, Istanbul.

[14] Randle, J. (2003) Bullying in the Nursing Profession. Journal of Advanced Nursing, 43, 395401. https://doi.org/10.1046/j.1365-2648.2003.02728.x

[15] Sengül, C. and Herken, H. (2009) From Genetics to Epigenetics: Alcohol Addiction. Anatolian Journal of Psychiatry, 10, 239-245.

[16] Isikli, S. and Irak, M. (2002) Drug Use and Addiction Research in Turkey: Drug Use Macro Scale Survey in 2002. Turkish Psychological Association, Ankara.

[17] Ozgur Ilhan, I, Demirbas, H. and Dogan, Y.B. (2005) A Study on Alcohol Use among Working Youth Who Are Continuing Apprenticeship Training. Turkish Journal of Psychiatry, 16, 237-244.

[18] Anderson, J.L. (1994) Treatment Considerations for the Addicted Nurse. Behavioral Health Management, 14, 22-26.

[19] Griffith, J. (1999) Substance Abuse Disorders in Nurses. Nursing Forum, 34, 19-28. https://doi.org/10.1111/j.1744-6198.1999.tb01167.x

[20] Akvardar, Y., Turkan A. and Cakmak, D. (2002) Is Substance Abuse among Physicians a Problem? Turkish Journal of Psychiatry, 13, 238-244.

[21] Yargic, I. (2009) Addiction Problems and Solutions in Health Care Workers. Journal of Clinical Development, 22, 84-87.

[22] Monroe, T.B., Kenaga, H., Dietrich, M.S., Carter, M.A. and Cowan, R.L. (2013) The Prevalence of Employed Nurses Identified or Enrolled in Substance Use Monitoring Programs. Nursing Research, 62, 10-15. https://doi.org/10.1097/NNR.0b013e31826ba3ca

[23] Bekar, O.E. (2014) Nurses with Addictive Substance Abuse and Nursing Management Approach: A Literature Review. Journal of Health and Nursing Management, 1, 43-47.

[24] Kose Baloglu, M. (2001) Usage of Psychoactive Drugs among Nurses Working in Hospitals in the Center of Denizli. Master's Thesis, Pamukkale University, Institute of Medical Sciences, Denizli.

[25] Selye, H. (1956) The Stress of Life. McGraw-Hill Book Company, New York.

[26] Baltas, A. and Baltas, Z. (2004) Stress and Coping Ways. Remzi Publications, Istanbul.

[27] Balci, A. (2000) Job Stress of Instructors: Theory and Practice. Nobel Publications, Ankara.

[28] Karabulut, S. (1996) Three Dimensions in Management. Research Coordination Center, Istanbul.

[29] Eren, E. (2004) Organizational Behavior and Psychology of Management. Beta Publications, Istanbul.

[30] Isikhan, V. (2004) Stress in Working Life and Coping Ways. Sandal Publications, Ankara.

[31] Leong, C.S., Furnham, A. and Cooper, C.L. (1996) The Moderating Effect of Organizational Commitment on the Occupational Stress Outcome Relationship. Human Relations, 49, 1345-1363. https://doi.org/10.1177/001872679604901004

[32] Gok, I. (2009) An Important Problem of Work Life: Organizational Stress. Marmara University Journal of Economic and Administrative Sciences, 27, 429-448.

[33] Duymaz, E.K. (1999) Managerial Stress Scale Reliability and Validity Study on Manager Nurses. Master's Thesis, Ege University, Institute of Medical Sciences, Izmir. 
[34] Ozdevecioglu, M. (2004) Effects on Professional Stress of Social Support and Life Satisfaction. Hacettepe University Journal of Economics and Administrative Sciences, 22, 209-233.

[35] Raitano, R.E. and Kleiner, B.H. (2004) Stress Management: Stressors, Diagnosis and Preventative Measures. Management Research News, 27, 32-38.

https://doi.org/10.1108/01409170410784446

[36] Genc, N. (2004) Management and Organization. Seckin Publishing, Ankara.

[37] Bakan, I. and Büyükbese, T. (2004) The Relationship of Employees Occupational Safety and General Business Conduct: A Case Study. Erciyes University Journal of Economics and Administrative Sciences, 23, 35-59.

[38] Ergeneli, A. and Eryigit, M. (2001) Job Satisfaction of Instructor: Comparison of State and Private Universities in Ankara. Hacettepe University Journal of Economics and Administrative Sciences, 19, 159-178.

[39] Avsaroglu, S., Deniz, M.E. and Kahraman, A. (2005) The Investigation of Life Satisfaction, Job Satisfaction and Professional Burnout Levels in Technical Teachers. Selçuk University the Journal of Institute of Social Sciences, 14, 115-129.

[40] Barutcugil, I. (2005) Strategic Human Resource Management. Kariyer Press, Istanbul.

[41] Aksu, G., Acuner, A. and Tabak, R. (2002) A Study on Job Satisfaction of Managers in the Central and Provincial Organizations of the Ministry of Health (Ankara Example). Journal of Ankara University Faculty of Medicine, 55, 271-282.

[42] Aktug, I.Y., Susur, A., Keskin, S., Balci, Y. and Seber, G. (2006) Burnout Levels of Physicians in Osmangazi University School of Medicine. Osmangazi Journal of Medicine, 28, 91101.

[43] Aslan, H., Aslan, O., Kesepara, C., Alparslan, N. and Unal, M. (1997) Work Related Tension, Exhaustion and Job Satisfaction at Health Personnel in Kocaeli. Community and Physician, 12, 24-29.

[44] Ozkan, S. (2008) The Effect of Role Conflict and Role Ambiguity on Burnout Levels of Physicians and Nurses. Master's Thesis, Hacettepe University, Institute of Medical Sciences, Ankara.

[45] Sayil, I., Haran, S., Olmez, S. and Ozgüven, H.D. (1997) Burn-Out in Medical Doctors and Nurses of Ankara University Medical School. Journal of Crisis, 5, 71-77.

[46] Sinat, O. (2007) A Research on the Burnout Level of the Nurses Working at Psychiatry Clinics. Master's Thesis, Istanbul University, Institute of Medical Sciences, Istanbul.

[47] Taze, S. (2008) Determining the Exhausted Level of the Nurses Working in Emergency and Intensive Care Unit. Master's Thesis, Marmara University, Institute of Medical Sciences, Istanbul.

[48] Tunc, T. (2009) The Relationship of Burnout with Role Conflict and Role Ambiguity in Physicians and Nurses: Sample of a University Hospital. Master's Thesis, Sakarya University, Institute of Social Sciences, Sakarya.

[49] Alacacioglu, A., Yavuzsen, T., Dirioz, M., Oztop, İ. and Yilmaz, U. (2009) Burnout in Nurses and Physicians Working at an Oncology Department. Psycho-Oncology, 18, 543548. https://doi.org/10.1002/pon.1432

[50] Bugdayci, R, Kurt, O., Sasmaz, T. and Oner, S. (2005) Depression Prevalence and Affecting Factors among General Practitioners and Specialists in Mersin Province. Health and Society, 15, 25-32.

[51] Cimen, M. and Ergin, C. (2001) A Survey on Burnout Levels of Turkish Armed Forces Heath Personnel. Gülhane Medical Journal, 43, 169-176. 
[52] Oguzberk, M. and Aydin, A. (2008) Burnout in Mental Health Professionals. Clinical Psychiatry, 11, 167-179.

[53] Arikan, F., Koksal, C.D. and Gökce, C. (2007) Work-Related Stress, Burnout, and Job Satisfaction of Dialysis Nurses in Association with Perceived Relations with Professional Contacts. Dialysis \& Transplantation, 4, 1-7.

[54] Ebrinc, S., Acikel, C., Basoglu, C., Cetin, M. and Celiköz, B. (2002) Anxiety, Depression, Job Satisfaction, Burnout and Coping with Stress in Nurses of a Burn Unit: A Comparative Study. Anatolian Journal of Psychiatry, 3, 162-168.

[55] Kalemoglu, M. and Keskin, Ö. (2006) Burnout Syndrome at the Emergency Service. Scandinavian Journal of Trauma, Resuscitation and Emergency Medicine, 14, 37-40.

[56] Taycan, O., Kutlu, L., Cimen, S. and Aydin, N. (2006) Relation between Sociodemographic Characteristics Depression and Burnout Levels of Nurse Working in University Hospital. Anatolian Journal of Psychiatry, 7, 100-108.

[57] Ferrinho, P., Biscaia, A., Fronteira, I., Craveiro, I., Antunes, A.R., Conceicao, C., Flores, I. and Santos, O. (2003) Patterns of Perceptions of Workplace Violence in the Portuguese Health Care Sector. Human Resources for Health, 1, 11. https://doi.org/10.1186/1478-4491-1-11

[58] Björkqvist, K. (2001) Social Defeat as a Stressor in Humans. Physiology \& Behavior, 73, 435-442. https://doi.org/10.1016/S0031-9384(01)00490-5

[59] Mayhew, C. and Chappell, D. (2001) Occupational Violence: Types, Reporting Patterns and Variations between Health Sectors: Taskforce on the Prevention and Management of Violence in the Workplace. Discussion Paper, No. 1, University of NSW, Sydney.

[60] Rutherford, A. and Rissel, C. (2004) A Survey of Workplace Bullying in a Health Sector Organization. Australian Health Review, 28, 65-72. https://doi.org/10.1071/AH040065

[61] Cox, H.C. (1987) Verbal Abuse in Nursing: Report of a Study. Nursing Management, 18, 47-50. https://doi.org/10.1097/00006247-198711000-00015

[62] Dilman, T. (2007) Defining the Situation of Mobbing Experience among the Nurses Working in Private Hospitals. Master's Thesis, Marmara Unversity, Institute of Medical Sciences, Istanbul.

[63] Gecici, N.B. and Sagkal, T. (2011) A Survey about the State of Nurses Who Experienced Mobbing in Odemis. Maltepe University Journal of Nursing Science and Arts, 4, 53-62.

[64] Yildirim, A. and Yildirim, D. (2007) Mobbing in the Workplace by Peers and Managers: Mobbing Experienced by Nurses Working in Health Care Facilities in Turkey and Its Effect on Nurses. Journal of Clinical Nursing, 16, 1444-1453. https://doi.org/10.1111/j.1365-2702.2006.01814.x

[65] Okanli, A., Karakas, S.A. and Ozkan, H. (2011) The Relationship between Mobbing and Assertiveness in Nurses. HealthMED, 5, 609-615.

[66] Nehir, S. (2003) The Determination of Work Related Stress Factors Ways of Coping Methods of Nurses Who Working in the Intensive Care Units of Ankara Hospitals. Master's Thesis, Abant Izzet Baysal University, Institute of Medical Sciences, Bolu.

[67] Bartram, J., Joiner, T.A. and Stanton, P. (2004) Factors Affecting the Job Stress of Australian Nurses: Implications for Recruitment and Retention. Contemporary Nurse, 17, 293-304. https://doi.org/10.5172/conu.17.3.293

[68] Draper, J., et al. (2004) NHS Cadet Schemes: Student Experience, Commitment, Job Satisfaction and Job Stress. Nurse Education Today, 24, 219-228.

https://doi.org/10.1016/j.nedt.2003.12.008 
[69] Rodham, K. (2002) Work Stress: An Exploratory Study of the Practices and Perceptions of Female Junior Healthcare Managers. Journal of Nursing Management, 10, 5-11. https://doi.org/10.1046/j.0966-0429.2001.00263.x

[70] Isikhan, V., Comez, T. and Danis, M.Z. (2004) Job Stress and Coping Strategies in Health Care Professionals Working with Cancer Patients. European Journal Oncology Nursing, 8, 234-244. https://doi.org/10.1016/j.ejon.2003.11.004

[71] Devebakan, N. (2007) Occupational Health and Safety in Private Health Care Organizations. PhD Thesis, Dokuz Eylül University, Institute of Social Sciences, Izmir.

[72] Erkol, H., Gokdogan, M.R., Erkol, Z. and Boz, B. (2007) Aggression and Violence towards Health Care Providers-A Problem in Turkey? Journal of Forensic and Legal Medicine, 14, 423-428. https://doi.org/10.1016/j.jflm.2007.03.004

[73] Ayranci, U., Yenilmez, C., Balci, Y. and Kaptanoglu, C. (2006) Identification of Violence in Turkish Health Care Settings. Journal of Interpersonal Violence, 21, 276-296. https://doi.org/10.1177/0886260505282565

[74] Annagür, B. (2010) Violence towards Health Care Staff: Risk Factors, after Effects, Evaluation and Prevention. Current Approaches in Psychiatry, 2, 161-173.

[75] Arcak, R. and Kasimoglu, E. (2006) Roles on the Health Care and the Pleasement at Work of the Nurses Working at the Hospitals and the Health Centres in Diyarbakir City. Dicle Medical Journal, 33, 23-30.

[76] Ozabaci, N. (1990) Investigation of Occupational Diseases and Causes among Nurses Working in Therapeutical Health Care Services. Master's Thesis, Istanbul University, Institute of Medical Sciences, Istanbul.

\section{Submit or recommend next manuscript to OALib Journal and we will provide best service for you:}

- Publication frequency: Monthly

- 9 subject areas of science, technology and medicine

- Fair and rigorous peer-review system

- Fast publication process

- Article promotion in various social networking sites (LinkedIn, Facebook, Twitter, etc.)

- Maximum dissemination of your research work

Submit Your Paper Online: Click Here to Submit

Or Contact service@oalib.com 